\title{
NOTES
}

\section{GIFFORD-HILL \& CO.v. FTC: DOES NEPA APPLY TO LAW-ENFORCEMENT ADJUDICATORY FUNCTIONS OF AN AGENCY?}

In Gifford-Hill \& Co. v. FTC, ${ }^{1}$ the District Court for the District of Columbia (per Gasch, J.) held that the National Environmental Policy Act (NEPA) ${ }^{2}$ does not apply to the FTC's initiation of an administrative proceeding to enforce the antitrust laws. GiffordHill, a corporation engaged in the production and sale of construction materials, had acquired over a five-year period certain concrete manufacturing and mining concerns. Because of the close relationship of the acquired companies to Gifford-Hill's business needs, the FTC decided to challenge these acquisitions as violative of the antitrust laws. ${ }^{3}$ Although Gifford-Hill availed itself of the FTC's consent order procedure, ${ }^{4}$ negotiations floundered over the FTC's demand that Gifford-Hill consent both to a divestiture of one of its acquisitions, Becker Sand \& Gravel Co., and to a ten-year prohibition on acquisitions of similar firms. ${ }^{5}$ After the FTC issued an administrative complaint, Gifford-Hill sought a federal court injunction ${ }^{6}$ against further prose-

1. 1974-2 Trade Cas. T 75,348 (D.D.C., Nov. 14, 1974), appeal docketed, No. 74-2024 (D.C. Cir., Nov. 14, 1974).

2. 42 U.S.C. $\$ \S 4321$ et seq. (1970).

3. The acquired firms included companies which manufactured ready-mixed concrete and concrete products, as well as concerns which mined "construction aggregates" (sand, gravel, etc.). 1974-2 Trade Cas. at 98,104 \& n.6. The FTC alleged that these mergers violated section 7 of the Clayton Act, 15 U.S.C. $\$ 18$ (1970) (an acquisition of a corporation or its assets which would substantially lessen competition or tend to create a monopoly is forbidden), and section 5 of the Federal Trade Commission Act, 15 U.S.C. $\$ 45$ (1970) (prohibition of unfair methods of competition and deceptive acts or practices). Administrative Complaint, In re Gifford-Hill \& Co., Docket No. 8989 (FTC, Aug. 7, 1974). In reaching its decision to file a complaint, the FTC relied on its criteria which are enumerated in the FTC's "Enforcement Policy with Respect to Vertical Mergers in the Cement Industry," released on Jan. 17, 1967. 1 Trade Reg. REP. If 4520, at 6901 (FTC 1972). See letter from James T. Halverson, Director, FTC Bureau of Competition, to Robert V. Barnes, Executive Vice President, Gifford-Hill \& Co., on file at the business office of the Duke Law Journal, Durham, North Carolina.

4. 16 C.F.R. $\S \S 2.31-.35$ (1974).

5. $1974-2$ Trade Cas. at 98,104 .

6. Id. The jurisdiction of the federal district court was invoked pursuant to, inter alia, 28 U.S.C. $\$ 1331$ (1970) (federal question jurisdiction). Declaratory relief was sought pursuant to 28 U.S.C. $\$ \S 2201-02$ (1970). Plaintiff's Verified Complaint for 
cution of the adjudicatory proceeding pending full FTC comphance with NEPA. ${ }^{7}$ Specifically, Gifford-Hill alleged that the FTC must estabhish appropriate NEPA procedures in regard to its adjudicatory procedures, ${ }^{8}$ properly consider environmental issues in relation to the prosecution of Gifford-Hill,' and file an environmental impact statement with regard to such prosecution. ${ }^{10}$ These allegations were buttressed by a claim that the enforcement of the FTC's demands might compel Gifford-Hill to begin its own strip mining operations, with resulting harm to the environment. ${ }^{11}$ In denying Gifford-Hill's request for a preliminary injunction, the court disagreed with the contention that such environmental damage would necessarily flow from the FTC's adjudications; ${ }^{12}$ furthermore the entire area of agency law-enforcement adjudication was held not to be within the contemplation of NEPA. ${ }^{13}$

NEPA imposes upon federal agencies both substantive and procedural duties in the interest of preserving and enhancing the nation's environment. ${ }^{14}$ As a general requirement, the Act almounces the fed-

Declaratory Judgment, Injunctive Relief \& Mandamus at 3, Gifford-Hill \& Co. v. FTC, 1974-2 Trade Cas. II 75,348 (D.D.C., Nov. 14, 1974), appeal docketed, No. 74-2024 (D.C. Cir., Nov. 14, 1974).

7. 1974-2 Trade Cas, at 98,103. Gifford-Hill also alleged that the FTC had violated NEPA by failing to consider and weigh adequately environmental concerns while it continued to implement the Cement Guidelines, see note 3 supra, and by failing to file an environmental impact statement for these Guidelines. Plaintiff's Verified Complaint, note 6 supra.

8. Id.

9. Id.

10. Id.

11. "[T] he only possible environmental effect suggested by GFH is that it might be required to mine sand and gravel for its own use if it must rid itself of Becker." Id. at 98,108 .

12. Id.

13. Id. By implication, the court upheld the validity of the FTC regulation exempting its own enforcement adjudicatory procedures from the NEPA impact statement requirement. 16 C.F.R. $\S 1.82$ (d) (1974). That section reads as follows:

Nothing in this procedure shall be construed as stating or implying that the requirements of section $102(2)$ (c) of the National Environmental Policy Act apply to: Any investigation made by the Commission for law enforcement purposes; any process or order issued by the Commission in connection with any type of investigation; any agreement of voluntary compliance or consent decree entered into by the Commission; or any adjudicatory proceedings commenced by the Commission. Id. (emphasis added).

The Council on Environmental Quality lias agreed with the FTC's interpretation of NEPA. See CEQ Advisory Memorandum, Application of the National Environmental Policy Act to Enforcement of Anti-Trust Laws by the Federal Trade Commission 10, Jan. 31, 1975, on file at the business office of the Duke Law Journal, Durham, North Carolina.

14. 42 U.S.C. $\$ 4331$ (a) (1970). See Calvert Cliffs' Coordinating Comm., Inc. v. AEC, 449 F.2d 1109, 1111 (D.C. Cir. 1971). 
eral government's responsibility to "use all practicable means, consistent with other essential considerations of national policy, to improve and coordinate federal plans, functions, programs and resources" in order to effectuate the purposes of the Act. ${ }^{15}$ To insure performance of these substantive duties, the Act imposes certain "action-forcing"10 procedural obligations ${ }^{17}$ which all federal agencies must observe "to the fullest extent possible." 18 The most general of these requirements are that agencies use an environmentally oriented approach ${ }^{19}$ and that procedures be developed to insure consideration of environmental factors. ${ }^{20}$ Among the specific "action-forcing" procedures, by far the most important is the requirement that each agency file an environmental impact statement in connection with "every recommendation or report on proposals for legislation and other major federal actions significantly affecting the quality of the human environment."21 This statement must be publisled ${ }^{22}$ and must accompany the government's proposal through "existing agency review processes." 23 The Act's broad sweep is further illuminated by the fact that no federal agency is exempted from its provisions.

Judicial determinations of the applicability of NEPA have fully

15. 42 U.S.C. $\$ 4331$ (b) (1970).

16. Section 102(2)'s procedural requirements were so characterized by Senator Henry M. Jackson, NEPA's principal sponsor. See Hearings on S. 1075, S. $237 \& S$. 1752 Before the Senate Comm. on Interior \& Insular Affairs, 91st Cong., 1st Sess. 116 (1969).

17. 42 U.S.C. $\$ 4332(2)(1970)$.

18. Id. $\$ 4332(1970)$. The intent of requiring compliance "to the fullest extent possible" was to insure that no agency would utilize an excessively narrow construction of its existing statutory authorizations to avoid compliance. 115 CoNG. REc. 40418 (1969); 115 CoNG. Rec. 39702-03 (1969). See 1973 CEQ Gumelines $\$ 1500.4(a)$.

19. 42 U.S.C. $\S 4332(2)(A)(1970)$ (requiring all agencies to "ntilize a systematic, interdisciplinary approach which will ensure the integrated use of the natural and social sciences and the environmental design arts in planning and evaluation in decision-making which may have an impact on man's environment").

20. 42 U.S.C. $\$ 4332(2)$ (B) (1970) (all agencies must "identify and develop methods and procedures .... which will insure that presently unqnantified environmental amenities and values may be given appropriate consideration in decisionmaking along with economic and technical considerations"). The word "appropriate" in this section does not give agencies "broad discretion to downplay environmental factors in their decision making processes." Calvert Cliffs' Coordinating Comm., Inc. v. AEC, 449 F.2d 1109, 1113 n.8 (D.C. Cir. 1971). See 1973 CEQ GUIDELINES $\$ 1500.6$ (c).

21. 42 U.S.C. $\$ 4332(2)$ (c) (1970). The environmental impact statement is a "detailed statement" which covers such matters as the environmental impact of the proposed action, unavoidable environmental effects that will occur should the proposal be implemented, and alternatives to the proposed action which might alter the cost-benefit equation. $1 d$.

22. The impact statement must be "made available to the President, the Council on Environmental Quality and to the public...."Id.

23. Id. 
recognized the expansive statutory language. The early leading case of Calvert Cliffs' Coordinating Committee, Inc. v. AEC ${ }^{24}$ set the tone for many subsequent decisions in holding that "[the] sweep of NEPA is extraordinarily broad, compelling consideration of any and all types of environmental impact of federal action."25 Relying heavily upon broad statements in the legislative history, ${ }^{26}$ the Court of Appeals for the District of Columbia Circuit rejected the AEC's narrow view of what should constitute compliance "to the fullest extent possible." ${ }^{27}$ The court's reasoning was that noncompliance should be excused only in the event of a "clear conflict of statutory authority."28 The general approach exemplified by Calvert Cliffs' has been followed in a wide variety of contexts, as courts have almost uniformly rejected any atteinpt to interpret the statute's scope as being narrower than a literal reading would indicate. ${ }^{29}$ Although no case other than Gifford-Hill has considered the applicability of NEPA to agency lawenforcement proceedings, ${ }^{30}$ several decisions have dealt with other types of adjudicatory proceedings. These cases have typically concerned agency decisions to authorize nonfederal actions such as the abandonment of a railway line, ${ }^{31}$ curtailment of natural gas sales, ${ }^{32}$

24. 449 F.2d 1109 (D.C. Cir. 1971).

25. Id. at 1122 .

26. 449 F.2d at 1114-15, quoting 115 CONG. REC. 40,417-18 (1969). See also S. Rep. No. 91-296, 91st Cong., 1st Sess. (1969); H.R. Rep. No. 91-378, 91st Cong., 1st Sess. (1969).

27. 449 F.2d at 1118 .

28. Id. at 1115.

29. In Jones v. District of Columbia Redevelopment Land Agency, 499 F.2d 502 (D.C. Cir. 1974), a case involving the appropriate time for filing a section 102(2)(c) impact statement with respect to a federal urban renewal project, the District of Columbia Circuit had occasion to examine the purpose of NEPA. Despite its holding that the agency's remedial activities had cured its noncompliance with NEPA, 499 F.2d at 513 , the court observed in passing that "NEPA was intended to ensure that decisions about federal actions would be made only after responsible decisionmakers had fully adverted to the environmental consequences of the actions, and had decided that the public benefits flowing from the actions outweighed their environmental costs." Id. at 512 . The court lias even applied NEPA to projects that were still in the developmental stage. See Scientists' Institute for Pub. Information, Inc. v. AEC, 481 F.2d 1079 (D.C. Cir. 1973). NEPA has also been applied to agency proceedings which considered the approval of private rather than federal action. See cases cited notes 31-35 infra.

30. Judge Gasch characterized Gifford-Hill as a case of first impression because it was the first time that a litigant had asked the court to apply NEPA to "a law-enforcement adjudicatory proceeding." 1974-2 Trade Cas. at 98,105.

31. See Harlem Valley Transp. Ass'n v. Stafford, 500 F.2d 328 (2d Cir. 1974) (ICC must decide if impact statement necessary prior to abandonment proceeding; if necessary it must be prepared before hearings); City of New York v. United States, 337 F. Supp. 150 (E.D.N.Y. 1972) (consideration of NEPA required before ICC could order abandonment of an entire railroad line).

32. See Louisiana v. FPC, 503 F.2d 844, 875 (5th Cir. 1974) (where curtailment 
the construction of a power facility, ${ }^{33}$ construction of a pipeline, ${ }^{34}$ or initiation of a private redevelopment project. ${ }^{35}$ Judicially created exemptions from the scope of NEPA have been confined to highly unusual circumstances. One case exempted orders of the Price Commission because of the temporary nature of the agency and the necessity that it make its decisions with dispatch. ${ }^{36}$ In another case, the need to follow "expeditious procedures" in ordering an interim curtailment of natural gas supplies was used to justify an exception to NEPA. ${ }^{37}$ The need for a quick administrative determination was also used to justify the court's refusal to apply NEPA to regulations promulgated by the Federal Energy Office. ${ }^{38}$ Furthermore, courts have refused to compel the application of NEPA to delay decisions by the Environmental Protection Agency. ${ }^{39}$

of gas supplies will be permanent, agency "must file best impact statement possible unless filing will conflict with a statutory duty"); Transcontinental Gas Pipe Line Corp. v. FPC, 488 F.2d 1325, 1330 (D.C. Cir. 1973) (FPC should consider the environmental effects of its decision to award gas supplies to one of two competing gas pipe lines).

33. See Greene County Planning Bd. v. FPC, 455 F.2d 412 (2d Cir.), cert. denied, 409 U.S. 849 (1972) (Power Authority of the State of New York sought permission to build high-voltage power transmission line).

34. See Arizona Pub. Serv. Co. v. FPC, 483 F.2d 1275, 1282 (D.C. Cir. 1973), reconsideration subsequent to remand, 490 F.2d 783 (D.C. Cir. 1974) (denial of certificate of public convenience and necessity under Section 7 of the Natural Gas Act, 15 U.S.C. $\$ \$ 717 f(c)$, (e) (1970)).

35. See McLean Gardens Residents Ass'n v. National Capitol Planning Comm'n, 2 ENVIRONMENTAL L. REP. 20659 (D.D.C., Oct. 21, 1972).

36. Cohen v. Price Comm'n, 337 F. Supp. 1236 (S.D.N.Y. 1972).

37. Atlanta Gas Light Co. v. FPC, 476 F.2d 142, 149-50 (5th Cir. 1973). In exercising its curtailment power, the FPC is authorized to follow summary procedures; a detailed evaluation of environmental impact would cause delay and would prevent a summary proceeding. Id. at 150 .

38. Gulf Oil Corp. v. Simon, 373 F. Supp. 1102 (D.D.C. 1974).

39. See Getty Oil Co. v. Ruckelshaus, 467 F.2d 349 (3d Cir. 1972), cert. denied, 409 U.S. 1125 (1973). Getty Oil alleged that a compliance order issued by the Administrator of the Environmental Protection Agency was ultra vires because EPA had not complied with section 102(2)(c) of NIEPA, 42 U.S.C. $\$ 4332(2)$ (C) (1970). The court did not believe that EPA is bound by NEPA, and even if NEPA did apply, the court concluded that Getty Oil should have raised the NEPA issue under section 307 of the Clean Air Act. 467 F.2d at 359.

In Portland Cement Ass'n v. Ruckelshaus, 486 F.2d 375 (D.C. Cir. 1973), cert. denied, 417 U.S. 921 (1974), the District of Columbia Circuit established a narrow exemption from NEPA applicable to EPA determinations under section 111 of the Clean Air Act but warned that "NEPA must be accorded full vitahty as to non-environmental agencies . . ." Id. at 387. Apparently decisive to the court's decision was its recognition that section 111 of the Clean Air Act requires the "functional equivalent of a NEPA impact statement." Id. at 384.

However, Congress has amended the Clean Air Act to clarify that NEPA would not in the future be applicable to cases like Getty Oil and Portland Cement. Act of June 22, 1974, Pub. L. No. 93-319, § 7(c) (1), 88 Stat. 259, amending 42 U.S.C. $\$ 1857$ 
The Gifford-Hill court offered two bases for its decision that the FTC need not comply with NEPA before prosecuting an administrative complaint against Gifford-Hill. As a general principle, according to the court, NEPA brings within its scope only those federal actions with "a reasonably substantial relationship to the quality of the environment." 40 This conclusion enabled the court to exempt the case before it from the operation of NEPA because of the unlikelihood of any environmental impact resulting froin the FTC proceeding. ${ }^{41}$ Furthermore, the court held that, even apart from the issue of environmental dainage, the nature of FTC law-enforcement proceedings would remove them from the aunbit of NEPA. ${ }^{42}$ Two broad categories of federal actions ${ }^{43}$ were seen as having a sufficient relationship to environmental quality to be subject to NEPA: (1) actions, such as federal construction projects, with a "direct federal impact on the environment," 44 and (2) actions by nonfederal parties which require prior federal permission. ${ }^{45}$ Because FTC law-enforcement adjudication belongs to neither group, the court believed that it sliould be immunized froin NEPA requirements even if there were possible environmental consequences. ${ }^{46}$ The court underscored its somewliat

(1970). See generally Note, Applicability of NEPA's Impact Statement Requirement to the EPA, 1974 DuKe L.J. 353.

40. 1974-2 Trade Cas. at 98,107. This conclusion was based both upon "the legislative history of NEPA" and "the case law surrounding the Act." Id.

41. The court found the allegations of possible environmental harm to be "exceedingly speculative," noting that Gifford-Hill would be free to purchase from the company (Becker Sand and Gravel) it had to sell even after the divestiture. Id. at 98,108. Indeed, the court concluded that even if the FTC succeeded in divesting Gifford-Hill of its interest in Becker, such action "is not that sort of action which would have an effect on the environment." Id. (emphasis added). In any case, the same environmental result vould occur if Gifford-Hill presently decided that it should open more mines and caused Becker to create them. Thus, Gifford-Hill's "spectre of a possible proliferation of strip mines around the landscape" did not seem to the court "a very imposing phantom." Id.

42. Id.

43. Id. at 98,107. "NEPA applies to those situations in which 'an agency proposes to build a facility itself, [and] also whenever an agency makes a decision which permits action by other parties which will affect the quality of the environment.'" Id., citing Scientists' Institute for Pub. Information, Inc. v. AEC, 481 F.2d 1079, 1088 (D.C. Cir. 1973).

44. 1974-2 Trade Cas. at $98,107 \&$ n.36.

45. Id. at n.37.

46. The court noted that if any environmental impact actually occurred after the divestiture it would be as the result of "unrelated private action." Id. at 98,109.

Judge Gasch also held that NEPA does not apply to the formulation and continued use of the "Enforcement Policy with Respect to Vertical Mergers in the Cement Industry," (see supra note 3 ). Id. at 98,108 . In noting that the guidelines represented at most a statement of the FTC's interpretation of the law, Judge Gasch considered the guidelines to be no more than a "warning" to the public "about those mergers which 
illogical reliance on the nature of agency action rather than upon environmental impact by suggesting that NEPA might apply to an FTC decision to grant approval for a merger ${ }^{47}$ - a lyypothetical situation which would fall within the second of the court's categories.

The two broad categories of federal actions suggested by Judge Gasch $^{48}$ can be criticized for their failure to be sufficiently inclusive. There is at least one reported case that lias applied NEPA to a situation which would not fit within either of the two described categories. $^{49}$ However, one must share the court's doubts that Congress actually intended NEPA to be used as a shield for continuing violations of the law; as the court noted, a similar rationale could be used to delay such administrative actions as an SEC order that a securities law violator be divested of illegal stockholdings, or an FDA decision to enforce prohibitions of harmful drugs. ${ }^{50}$ It is evident that, at the very least, a substantial question exists as to whether Congress intended

might be deemed improper by the FTC." Id. If the guidelines had been labeled a "policy" rather than a "warning" it would seem more likely that NEPA would be applicable. The Council on Environmental Quality has said that "action[s] requir[ing] the preparation of an environmental statement . . . include but are not limited to . . . [p]olicy, regulations, and procedure-making." Statements on Proposed Federal Actions Affecting the Environment, 36 Fed. Reg. 7724 (1971). Although the CEQ in its Advisory Memorandum, supra note 13 , at 28 , concluded that the guidelines are potentially subject to the requirement of filing an impact statement, no impact statement was necessary because "a close inspection of them indicates that specific environmental impacts cannot be attributed to their continued implementation." Id. at 29. The CEQ Advisory Memorandum explained further that "the potential environmental effects [of the guidelines] are not great, and are clearly not dispositive of whether the FTC should generally proceed against vertical acquisitions in the cement industry." Id. at 31 .

47. 1974-2 Trade Cas. at 98,108. Because Gifford-Hill had merged in defiance of the FTC's 'Enforcement Policy with Respect to Vertical Mergers in the Cement Industry," supra note 3, the court was unwilling to characterize the proceeding as one where Gifford-Hill was seeking "permission" after it had accomplished the merger. Id.

The Gifford-Hill court's reasoning would seem to justify exempting any FTC consideration of mergers from NEPA because whatever impact the corporations might have on the environment as separate entities would likely be the same after they have beeu combimed to form a new entity.

In its consideration of industrial concentration, the FCC's position is that diversity of ownership of communications facilities is not a matter which can have any "discernible impact on the physical environment [and] cannot be held to require preparation of an impact statement, no matter what social, economic or moral issues may otherwise be presented." Implementation of the National Environmental Policy Act of 1969; Termination of Proceeding, Part I, II 11, 39 Fed. Reg. 43,834 \& 43,836 (1974).

48. See text accompanying notes $43-45$ supra.

49. See United States v. SCRAP, 412 U.S. 669 (1973) (student coalition successfully enjoined ICC order not to suspend freight surcharge for seven-month period on ground that ICC had not complied with NEPA).

50. 1974-2 Trade Cas. at 98,108-09. The court regarded such cases as "plainly beyond the ambit of NEPA." Id. at 98,109. 
that NEPA should apply to enforcenent proceedings of this sort. In the absence of any legislative history directly on point, ${ }^{51}$ one inust turn to a consideration of the policies of the Act. ${ }^{52}$ That the parainount purpose of NEPA was to protect the environment is obvious froin even the inost casual reading of the statute's introductory sections announcing the Act's policies. ${ }^{53}$ However, the sane provisions make it clear that the administration of NEPA is to be "consistent with other essential considerations of national policy," $" 54$ and in three decisions $^{55}$ courts have exempted agencies from NEPA. Speaking of this issue one court said, "the legislative history of the NEPA interprets [coinpliance] 'to the fullest extent possible' to mean compliance unless comphance would give rise to a violation of statutory obligations." "5o Since all of these cases involved a statutory duty to reach a prompt decision, ${ }^{57}$ they could be narrowly read to say that "statutory impossibility" preventing compliance with NEPA will only arise when the agency inust nneet a stringent deadline. The cases einphasize how difficult it is for an agency to justify an exception to NEPA: "the Coinnnission's duty under the Natural Gas Act to prevent discriminatory practices in times of gas shortage called for prompt action. This created the type of 'statutory conflict' which alone can excuse compliance with [NEPA's impact statement requirement]." ${ }^{58}$ Nevertheless, these cases which have granted exceptions to NEPA can be given a broader meaning. In essence, the courts have subordinated the policies of NEPA to the policies of other programs enacted by Congress.

51. For the legislative history of NEPA, see H.R. REP. No. 91-378, 91st Cong., 1st Sess. (1969); S. REP. No. 91-296, 91st Cong., 1st Sess. (1969); 2 U.S. CodE CoNG. \& AD. NEws 2751 et seq. (1969).

52. This conclusion is merely an application of the well-known doctrine that the policies underlying legislation must be considered if the statute's application is unclear. See United States v. Sisson, 399 U.S. 267, $297-98$ (1970); District of Columbia v. Orleans, 406 F.2d 957, 958-59 (D.C. Cir. 1968); In re National Guard, 71 Vt. 493, 499, 45 A. 1051, 1053 (1899); 2 C. SANDS, Statutes AND Statutory CONSTRUCtion $\$ 47.04$ (4th ed. 1972).

53. See 42 U.S.C. $\$ 4331$ (1970).

54. Id. $\S 4331$ (b) (1970).

55. Atlanta Gas Light Co. v. FPC, 476 F.2d 142, 148 (5th Cir. 1973) (natural gas shortage necessitates a curtailment process which allows the commission "to act 'now' and find facts later"); Gulf Oil Corp. v. Simon, 373 F. Supp. 1102, 1104-05 (D.D.C. 1974) (FEO administrator directed by Congress to promulgate mandatory oil allocations within fifteen days of legislation's enactment); Cohen v. Price Comm'n, 337 F. Supp. 1236, 1241 (S.D.N.Y. 1972) (to function effectively, the Price Commission must act expeditiously).

56. Atlanta Gas Light Co. v. FPC, 476 F.2d 142, 150 (5th Cir. 1973).

57. See cases cited note 55 supra.

58. American Smelting \& Ref. Co. v. FPC, 494 F.2d 925, 948 (D.C. Cir. 1974) (emphasis added). 
Without speed, these programs could not exist; the courts concluded that Congress wanted these programs implemented even at the expense of NEPA. Such an approach is consistent with the language of NEPA which imdicates that the policies and goals of NEPA are "supplementary to those set forth in existing authorizations of Federal agencies." ${ }^{\text {59 }}$ Furthermore, the Supreme Court has indicated that "NEPA was not intended to repeal by implication any other statute."60 Thus, while the FTC may not be able to argue successfully that it should be excused from filing impact statements for its adjudicatory proceedings because of any unique need for urgency, ${ }^{81}$ it can suggest that the application of NEPA would cause a partial repeal of the statutes under which the FTC operates. This argument assunies that a case would arise where the environmental impact of an FTC adjudicatory proceeding was so harmful that the FTC would discontinue its suit. As a result the law would no longer be in effect for those defendants who could claim that substantial environmental harm would result if they were sued. This partial repeal could be avoided if it were assunied that under no set of facts could the environmental harm ever be substantial enough to stop the FTC from enforcing the laws for which it has responsibility. However, under this assumption, the impact statement is predestined to be an exercise in futility, and the courts will not require the litigant to perform a futile act. Nevertheless, there may be some rooin for the FTC to consider the environmental impact of its adjudicatory proceedings. Consideration could be given to this matter when the FTC fashions a remedy. If the FTC has two or more possible remedies for the violations by a defendant, then the FTC should consider evidence presented by the parties as to the potential environmental impact of each potential remedy. With this information, the FTC would attempt to fashion a remedy consistent with its obligation to enforce the antitrust laws which would at the

59. 42 U.S.C. $\$ 4335$ (1970).

The effect of this section ... . is to give recognition to the fact that the bill does not repeal existing law. This section does not, however, obviate the requirement that the Federal agencies conduct their activities in accordance with the provisions of this bill unless to do so would clearly violate their existing statutory authorizations. CONF. REP. No. 91-765, 91st Cong., 1st Sess. (1969), printed in 2 U.S. CODE CONG. \& AD. NEWS 2767, 2771 (1969).

60. United States v. SCRAP, 412 U.S. 669, 694 (1973).

61. "Considerations of administrative difficulty, delay or economic cost will not suffice to strip [NEPA] of its fundamental importance." Calvert Cliffs' Coordinating Comm., Inc. v. AEC, 449 F.2d 1109, 1115 (D.C. Cir. 1971).

In some cases the FTC might be able to argue that its adjudicatory proceedings had to be concluded promptly because, if they were delayed by an impact statement, the antitrust violations could have so weakened the competitors of a violator that the efforts of the FTC to restore competitiveness might be severely hampered. 
same time produce the least environmental harm. ${ }^{82}$ This approach would give some recognition to environmental values while at the same time deterring defendants from using NEPA to postpone the adjudication of their alleged violations.

62. The CEQ in its Advisory Memorandum, supra note 13, agrees with this conclusion: "While the adversarial nature of the FTC's enforcement proceedings may not completely substitute for the inquiry that would otherwise occur under [NEPA], it does, in our view, yield a "workable balance between some of the advantages and disadvantages of full application of NEPA.'" Id. at 25 [citation omitted]. 